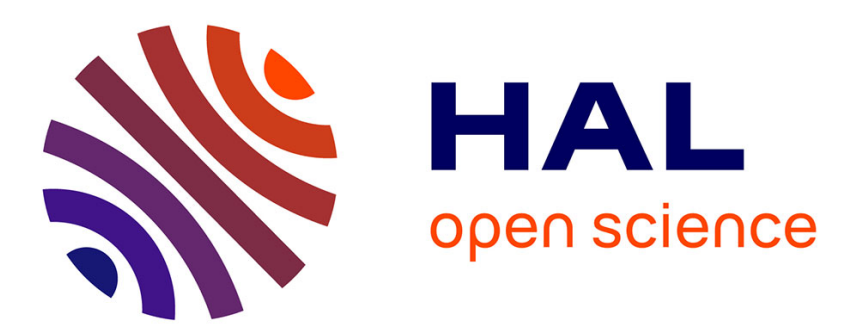

\title{
Supported Cobalt Catalysts for Acceptorless Alcohol Dehydrogenation
}

K. Kazmierczak, C. Pinel, S. Loridant, M. Besson, Carine Michel, N. Perret

\section{To cite this version:}

K. Kazmierczak, C. Pinel, S. Loridant, M. Besson, Carine Michel, et al.. Supported Cobalt Catalysts for Acceptorless Alcohol Dehydrogenation. ChemPlusChem, 2020, 85 (6), pp.1315-1324. 10.1002/cplu.202000359 . hal-02903128

\section{HAL Id: hal-02903128 \\ https://hal.science/hal-02903128}

Submitted on 9 Nov 2020

HAL is a multi-disciplinary open access archive for the deposit and dissemination of scientific research documents, whether they are published or not. The documents may come from teaching and research institutions in France or abroad, or from public or private research centers.
L'archive ouverte pluridisciplinaire HAL, est destinée au dépôt et à la diffusion de documents scientifiques de niveau recherche, publiés ou non, émanant des établissements d'enseignement et de recherche français ou étrangers, des laboratoires publics ou privés. 


\title{
Supported Cobalt Catalysts for Acceptorless Alcohol Dehydrogenation
}

\author{
Kamila Kaźmierczak, ${ }^{[a, b]}$ Catherine Pinel, ${ }^{[a]}$ Stéphane Loridant, ${ }^{[a]}$ Michèle Besson, ${ }^{[a]}$ Carine Michel, ${ }^{[b]}$ \\ Noémie Perret*[a]
}

[a] Dr K.Kaźmierczak, Dr C.Pinel, Dr S.Loridant, Dr M.Besson, Dr N.Perret IRCELYON

Univ Lyon, Université Claude Bernard Lyon 1, CNRS,

F-69626, Villeurbanne, France

E-mail: noemie.perret@ircelyon.univ-lyon1.fr

[b] Dr K.Kaźmierczak, Dr C.Michel

Laboratoire de Chimie

Univ Lyon, ENS de Lyon, CNRS, Université Claude Bernard Lyon 1 ,

46 Allée d'Italie, 69342, Lyon, France

Supporting information for this article is given via a link at the end of the document.

\begin{abstract}
The acceptor-less dehydrogenation of 2-octanol was tested over Co supported on $\mathrm{Al}_{2} \mathrm{O}_{3}, \mathrm{C}, \mathrm{ZnO}, \mathrm{ZrO}_{2}$ and various $\mathrm{TiO}_{2}$. The catalysts were characterized by ICP, XRD and TGA- $\mathrm{H}_{2}$. For $\mathrm{Co} / \mathrm{TiO}_{2} \mathrm{P} 25$, the effects of passivation, aging (storage at room temperature), and in situ activation under $\mathrm{H}_{2}$ were investigated. The catalysts have to be tested shortly after synthesis, in order to prevent deactivation. Co supported on $\mathrm{TiO}_{2} \mathrm{P} 25$ was the most active and $69 \%$ yield of 2-octanone was obtained, using decane as a solvent. Selectivity to 2-octanone in the range of $90 \%$ to $99.9 \%$ were observed. Small amounts of C16 compounds were also formed due to aldol condensation/dehydration reactions. The catalysts exhibited higher conversion for the dehydrogenation of secondary alcohol (65-69\%), in comparison to primary alcohol (2-10\%). The dehydrogenation of 1,2-octanediol led principally to 1-hydroxy-2-octanone, with a selectivity of $90 \%$ and $69 \%$ for $\mathrm{Co} / \mathrm{TiO}_{2} \mathrm{P}_{25}$ and $\mathrm{Co} / \mathrm{TiO} \mathrm{O}_{2} \mathrm{P} 90$, respectively.
\end{abstract}

\section{Introduction}

Transformation of alcohols into the corresponding carbonyl compounds is of high interest due to broad range of applications of carbonyls in pharmaceuticals, perfumes, as food additives and in disinfectants. ${ }^{[1-3]}$ Strong oxidants, including permanganate and chromate ${ }^{[4]}$ have been employed for this purpose. However, the stoichiometric use of these toxic oxidants generates large amounts of heavy-metal wastes. A better way is to develop catalytic systems using clean oxidants, such as $\mathrm{O}_{2}$ and $\mathrm{H}_{2} \mathrm{O}_{2},{ }^{[5]}$ which produce water as the sole by-product. Else, alcohol dehydrogenation can be performed in the presence of a sacrificial organic hydrogen acceptor (e.g. styrene $^{[6]}$ or ketone $\left.{ }^{[7]}\right)$, but this also generates stoichiometric organic product that requires to be separated afterwards. In the presence of additional molecules, hydrogen-borrowing strategy can lead to the synthesis of valuable chemicals ${ }^{[8-10]}$. Regarding atom economy, the most attractive method seems to be the acceptor-less alcohol dehydrogenation (AAD) reaction, in which from an alcohol only the corresponding carbonyl compound and $\mathrm{H}_{2}$ are generated. Furthermore, the produced gaseous $\mathrm{H}_{2}$ can potentially be used as highly energetic fuel. ${ }^{[11,12]}$ Nonetheless, this reaction requires an inert atmosphere to adopt the acceptor-less mechanism, and elevated temperature (over $100^{\circ} \mathrm{C}$ ) to proceed..$^{[13,14]}$

Different homogeneous ${ }^{[15-17]}$ and heterogeneous metal catalysts have been reported to facilitate the AAD reaction. Even though homogeneous catalysts are often reported to exhibit very good performances, they also frequently require the use of additives (such as acids or bases), and they are not easy to separate after experiments. These issues can be overcome with heterogeneous catalysts, such as supported metal catalysts. Noble metal-based catalysts, i.e. $\mathrm{Pt},{ }^{[18]} \mathrm{Pd},{ }^{[19]} \mathrm{Ru},{ }^{[20,21]} \mathrm{Re},{ }^{[22]} \mathrm{Au},{ }^{[23-25]}$ and $\mathrm{Ag},{ }^{[26-30]}$ have been shown to be active towards acceptor-less alcohol dehydrogenation. Due to their higher abundancy and lower costs, non-noble metal catalysts have also been investigated, namely $\mathrm{Cu}_{,}{ }^{[31-33]} \mathrm{Ni},{ }^{[34,35]}$ and $\mathrm{Co}^{[36]}$ which proved to be also active.

For most supported metal catalysts active in AAD reaction, the nature of the support is crucial for their performance. For example, it was determined by Shimizu et al. that $\mathrm{Ni}$ catalyst is the most active when amphoteric $\theta-\mathrm{Al}_{2} \mathrm{O}_{3}$ is used as a carrier. ${ }^{[34]}$ Mechanistic investigations proved the participation of acid or basic sites of the support in the alcohol dehydrogenation. In the first step alcohol molecule $\left(\mathrm{R}_{2} \mathrm{CHOH}, \mathrm{R}\right.$ - alkyl group) is adsorbed on the interface between metal nanoparticle and the support. O binds with Lewis acid site $\mathrm{Al}^{3+}$, while hydrogen from $\mathrm{OH}$ group binds with negatively charged $\mathrm{Al}-\mathrm{O}^{2-}$. The $\mathrm{O}-\mathrm{H}$ bond scission leads to the formation of an alkoxy intermediate. The following $\mathrm{C}-\mathrm{H}$ bond breaking takes place on the $\mathrm{Ni}^{0}$ nanoparticle, leading to the formation of the corresponding carbonyl product $\left(\mathrm{R}_{2} \mathrm{CO}\right)$. At last, $\mathrm{H}_{2}$ molecule is formed by combination of the neighbouring $\mathrm{H}$ atoms adsorbed on the metal particle and the support. By DFT computations it was demonstrated that the involvement of metal-support interface leads to the significant decrease of $\mathrm{O}-\mathrm{H}$ bond breaking activation energy for $\mathrm{Ni} / \mathrm{\theta}-\mathrm{Al}_{2} \mathrm{O}_{3}$ in comparison with the isolated $\mathrm{Ni}_{13}$ cluster. ${ }^{[37]}$ The acid-base properties of the support are crucial and supports of amphoteric nature were found to enhance the activity of catalysts. For $\mathrm{Pt},{ }^{[18]} \mathrm{Re},{ }^{[22]} \mathrm{Ag},{ }^{[29]}$ and $\mathrm{Ni}^{[34]}$ catalysts the most beneficial support was $\mathrm{Al}_{2} \mathrm{O}_{3}$, while for $\mathrm{Co}^{[36]} \mathrm{TiO}_{2}$ was preferred, and for $\mathrm{Au}^{[24]}$ and $\mathrm{Cu}^{[31]} \mathrm{HT}$ (hydrotalcite) was favoured. This implies that the optimal support should be identified depending on the metal.

Not only the activity of catalysts, but also their (chemo)selectivity is important for further applications. Alcohol substrates can contain both primary and secondary hydroxyl groups, as for many biomass-derived polyalcohols. It may be important to dehydrogenate 
selectively only one of the $\mathrm{OH}$ groups. To determine the appropriate catalyst for this purpose, dehydrogenation of primary and secondary monoalcohols of similar structures can be performed first. In this regard, some catalysts, such as $\mathrm{Ag}_{\mathrm{HTT}}{ }^{[27]} \mathrm{Ag} / \mathrm{Al}_{2} \mathrm{O}_{3}{ }^{\left[{ }^{[29]}\right.}$ and $\mathrm{Co} / \mathrm{TiO}_{2},{ }^{[36]}$ have been tested towards dehydrogenation of 1-octanol and 2-octanol, used respectively as model primary and secondary aliphatic linear alcohols. All these catalysts were more active towards the dehydrogenation of secondary alcohol, but they were not tested for selective diol(s) dehydrogenation.

In this work, the performance of cobalt supported catalyst for the acceptor-less alcohol dehydrogenation was investigated (Scheme 1). Based on the literature, ${ }^{[36]} \mathrm{Co} / \mathrm{TiO}_{2}$ was chosen as the starting catalyst, and its activity towards model secondary linear aliphatic alcohol dehydrogenation, namely 2-octanol, was examined. The influence of different parameters, such as the post-treatment (passivation) duration, aging (storage at room temperature), and possibility of re-activation by in situ $\mathrm{H}_{2}$ pre-treatment of the catalyst under the reaction conditions was studied. Subsequently, the effect of the nature of the support, in particular the crystallographic composition of $\mathrm{TiO}_{2}$, was explored. The most active catalysts were further tested in dehydrogenation of primary alcohol (1-octanol) and diol (1,2octanediol).

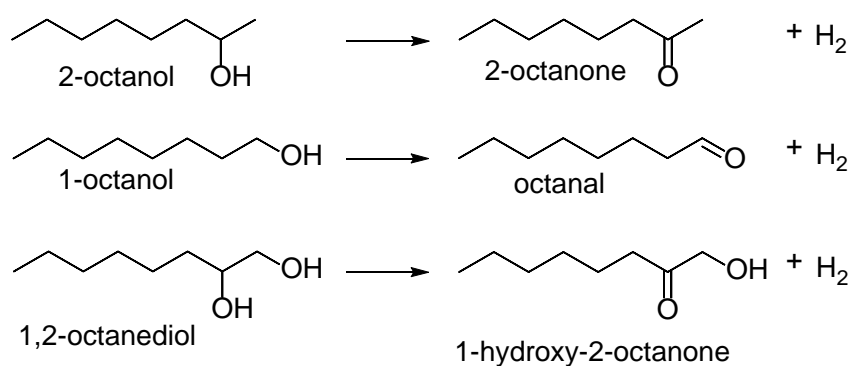

Scheme 1. Dehydrogenation of several alcohols.

\section{Results and Discussion}

\section{Dehydrogenation reaction under acceptor-less conditions}

$\mathrm{Co} / \mathrm{TiO}_{2} \mathrm{P} 25$ catalyst was tested for the dehydrogenation of 2-octanol at $145^{\circ} \mathrm{C}$, one week after synthesis and ex situ reduction. Figure 1 presents the profiles of 2-octanol conversion and yields of 2-octanone and $\mathrm{H}_{2}$ (Figure 1.a) and $\mathrm{H}_{2}$ production (Figure 1.b) as function of time. Conversion of 2-octanol reached $70 \%$ after $24 \mathrm{~h}$ (see Table 1, entry 1 ). The yield of 2-octanone was equal to $66 \%$ and yield of $\mathrm{H}_{2}$ was $58 \%$. The difference between these values is significant and suggests that $\mathrm{H}_{2}$ and 2-octanone were used in the formation of observed by-products. Nevertheless, the registered production of $\mathrm{H}_{2}$ confirms that the reaction proceeds via the acceptor-less mechanism, otherwise other molecules would have been formed, such as water in presence of oxygen. The selectivity towards 2 octanone was equal to 95\% at the end of the experiment (Figure S1) and four additional peaks were observed and identified as C16 substances. According to the literature, they may originate from aldol condensation ${ }^{[38,39]}$ or esterification ${ }^{[40,41]}$ reactions, which additionally can be followed by hydrogenation. To better identify their structures, GC-GC analyses were performed and an example of registered mass spectra is presented in Figure S2. Based on the mass of molecular ion, the C16 substances were identified as coming from aldol condensation/dehydration reaction, and possibly a sequential hydrogenation, and being a mixture of isomers and/or diastereomers. This could explain the lower yield in $\mathrm{H}_{2}$. Their proposed structures are presented in Figure S3.

\section{Influence of catalyst post-treatment, aging and activation}

Co is an oxophilic metal, and it requires protection against uncontrolled oxidation by air, which can deactivate the catalyst. Its preservation can be achieved by a passivation step which is associated with the formation of a tiny surface layer (ideally a monolayer) of $\mathrm{CoO}$ by treating the catalyst with $\mathrm{O}_{2}$ or $\mathrm{N}_{2} \mathrm{O}$ diluted in inert gas. ${ }^{[42]} \mathrm{Hence}$, one of the aims of our work was to investigate the influence of the duration of post-treatment (passivation) and aging (storage at room temperature) on the activity and selectivity of $\mathrm{Co} / \mathrm{TiO}_{2} \mathrm{P} 25$ catalyst in 2-octanol dehydrogenation.

Different durations of passivation and catalyst aging were tested for the supported $\mathrm{Co} / \mathrm{TiO}_{2} \mathrm{P} 25$ catalyst and the corresponding catalytic results are collected in Table 1. When the catalysts were passivated at room temperature for $0.5 \mathrm{~h}$ (entry 2 ) or $2 \mathrm{~h}$ (entry 8 ) and tested the same day, they did not differ in activity and gave conversions of $\sim 70 \%$ after $24 \mathrm{~h}$. This conversion is the same as for the nonpassivated catalyst (entry 1), transferred to the reactor via a glovebox. This suggests that the passivation treatment does not affect the catalytic performance when the catalyst is used directly after synthesis. However, when the catalyst was stored for two weeks before testing (two weeks of aging), the one passivated for $2 \mathrm{~h}$ showed lower activity ( $50 \%$ of conversion, entry 9$)$ than the catalyst passivated only for $0.5 \mathrm{~h}$ (73\% of conversion, entry 4$)$. This indicates that the $\mathrm{CoO}$ layer formed during passivation is evolving with time and this phenomenon is more important for the longer passivation time. Furthermore, increasing the aging to a few months lead to complete deactivation of the catalyst (entry 6). This implies that, although the samples were kept in a glovebox, the storage time is significant for the catalyst activity. 
(a)

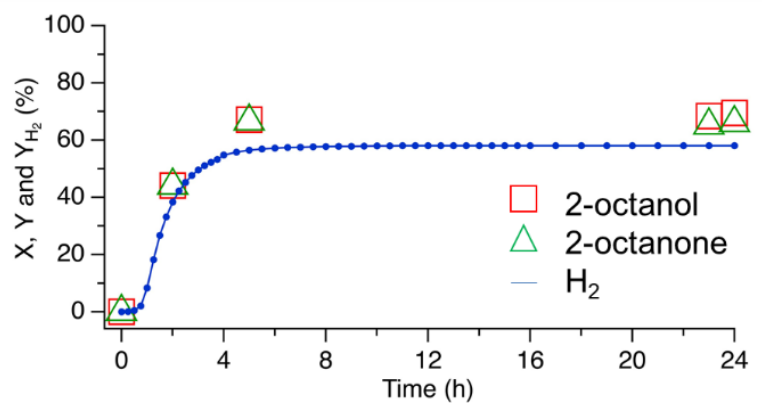

(b)

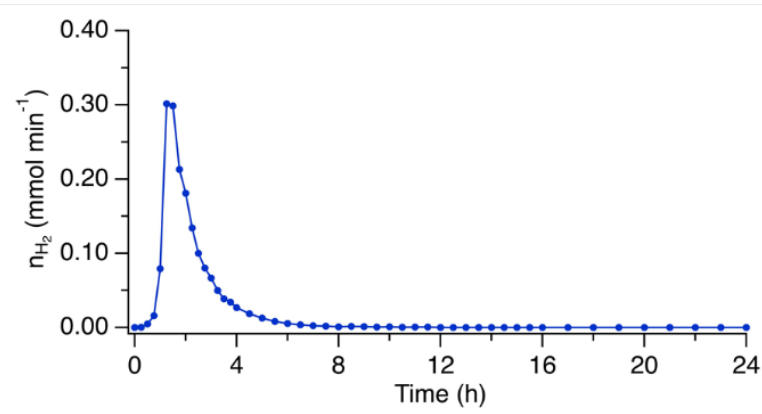

Figure 1. (a) Conversion of 2-octanol ( $\mathrm{X}, \quad$ ) and yields of 2-octanone $\left(\mathrm{Y}, \quad\right.$ ) and $\mathrm{H}_{2}\left(\mathrm{Y}_{\mathrm{H} 2}, \bullet\right)$ vs time, (b) $\mathrm{H}_{2}$ production ( $\left.\mathrm{n}_{\mathrm{H} 2}\right)$ vs. time, for 2-octanol dehydrogenation over $\mathrm{Co} / \mathrm{TiO}_{2}$ P25 catalyst, not passivated, tested one week after ex situ reduction. Reaction conditions: $0.5 \mathrm{~g}$ of $\mathrm{Co} / \mathrm{TiO}{ }_{2} \mathrm{P} 25$, $0.95 \mathrm{~mol} \mathrm{~L}^{-1}$ 2-octanol, decane, $145^{\circ} \mathrm{C}, \mathrm{V}_{\text {total }}=45 \mathrm{~mL}$.

Table 1. Effects of catalyst aging, duration of the passivation and in situ $\mathrm{H}_{2}$ pre-treatment on conversion, selectivity and yield of $\mathrm{Co} / \mathrm{TiO}{ }_{2} \mathrm{P} 25$ catalyst in 2 -octanol dehydrogenation [a]

\begin{tabular}{|c|c|c|c|c|c|c|c|}
\hline Entry & Passivation (h) & $\begin{array}{c}\text { Time between reduction } \\
\text { and reaction }\end{array}$ & $\begin{array}{c}\text { In situ } \mathrm{H}_{2} \text { pre- } \\
\text { treatment }\end{array}$ & X (\%) & S (\%) & Y (\%) & $\mathrm{Y}_{\mathrm{H} 2}(\%)$ \\
\hline $\begin{array}{l}0-\text { blank } \\
\text { reaction }\end{array}$ & n.a. & n.a. & n.a. & 4 & n.a. & n.a. & 0 \\
\hline 1 & none & 1 week & No & 70 & 95 & 66 & 58 \\
\hline 2 & \multirow{5}{*}{0.5} & \multirow{2}{*}{ The same day } & No & 70 & 98 & 69 & 64 \\
\hline 3 & & & Yes & 69 & 99 & 69 & 66 \\
\hline 4 & & \multirow{2}{*}{2 weeks } & No & 73 & 96 & 70 & 63 \\
\hline 5 & & & Yes & 77 & 98 & 76 & 75 \\
\hline 6 & & 6 months & No & 1 & n.a & n.a. & 0 \\
\hline 8 & \multirow{3}{*}{2} & The same day & No & 71 & 96 & 68 & 66 \\
\hline 9 & & \multirow{2}{*}{2 weeks } & No & 50 & 99 & 50 & 45 \\
\hline 10 & & & Yes & 64 & 98 & 63 & 61 \\
\hline
\end{tabular}

[a] Reaction conditions: $0.5 \mathrm{~g}$ of $\mathrm{Co} / \mathrm{TiO}_{2} \mathrm{P} 25,0.95 \mathrm{~mol} \mathrm{~L}^{-1}$ 2-octanol, decane, $\mathrm{V}_{\text {total }}=45 \mathrm{~mL}, 24 \mathrm{~h}, 145^{\circ} \mathrm{C}$. n.a. - not applicable

To go further, TGA- $\mathrm{H}_{2}$ analyses (Figure S4) were performed on the catalysts calcined, reduced, passivated for $0.5 \mathrm{~h}$, and stored for different periods (the same day, 2 weeks and 6 months after post-treatment). For comparison, the catalyst which was only calcined $\left(\mathrm{Co}_{3} \mathrm{O}_{4} / \mathrm{TiO}_{2} \mathrm{P} 25\right.$; see Figure S5 for its XRD analysis) was also analysed. For calcined catalyst, $\mathrm{Co}_{3} \mathrm{O}_{4}$ was first reduced to CoO at $320{ }^{\circ} \mathrm{C}$, and subsequently to $\mathrm{Co}$ at $450{ }^{\circ} \mathrm{C}$. For the reduced and passivated catalysts, only one reduction step was observed and ascribed to the $\mathrm{CoO}$ transformation into $\mathrm{Co}$. In case of the catalysts analysed the same day and 2 weeks after the reduction-passivation, the transformation occurred at $200{ }^{\circ} \mathrm{C}$, implying that the reduction of surface oxide is significantly facilitated in comparison with $\mathrm{Co}_{3} \mathrm{O}_{4} / \mathrm{TiO}_{2} \mathrm{P} 25$. The similarity between the analysis of these two catalysts indicates that they should be comparably active, which is in agreement with the catalytic test results. It was observed by Wolf et al. that the reduction of partially oxidized Co NPs was easier than the reduction of calcined catalyst. ${ }^{[43]}$ For the catalyst aged for 6 months, however, the transformation of CoO into Co occurred at $380^{\circ} \mathrm{C}$, suggesting the reduction of a thicker layer of $\mathrm{CoO}$. Moreover, the weight loss is higher ( $\left.3.5 \mathrm{wt} \%\right)$ in comparison with the samples analysed the same day and 2 weeks after reduction-passivation (1.5 wt\%). This proves the on-going gradual oxidation of Co metal with time, in agreement with the analysis reported for $\mathrm{Co} / \mathrm{SiO}_{2} \cdot{ }^{[33]}$ It also explains the lack of activity for the catalyst tested 6 months after the post-treatment.

We then investigated if it was possible to re-activate $\mathrm{Co} / \mathrm{TiO}_{2} \mathrm{P} 25$ catalyst by in situ $\mathrm{H}_{2}$ pre-treatment, under the reaction conditions (see Experimental section, in situ $\mathrm{H}_{2}$ pre-treatment). This in situ $\mathrm{H}_{2}$ treatment did not affect the activity of the catalyst with a thin CoO layer (passivated $0.5 \mathrm{~h}$ and tested the same day and 2 weeks later, entries 3 and 5, Table 1). However, for the catalyst with thicker oxide layer on the surface (passivated for $2 \mathrm{~h}$ and tested 2 weeks after reduction, entry 10) the change was noticeable. $\mathrm{H}_{2}$ pre-treatment of the catalyst increased the conversion up to $64 \%$, close to the one obtained with the catalyst tested on the same day. Moreover, for the catalyst passivated for $0.5 \mathrm{~h}$ and reduced 6 months before the reaction, the activity was re-gained, with $65 \%$ of conversion vs $1 \%$ (entry 7 vs entry 6). One should also notice, that the $\mathrm{H}_{2}$ production in the presence of the in situ pre-treated catalysts started immediately and intensively, whereas it was increasing gradually for the non-pre-treated catalysts (see Figure S6 for an example). Taking into account all the reaction results gathered in Table 1 it can be observed that the selectivity towards 2-octanone was always exceeding 95\%. Moreover, the formation of C16 by-products occurred when the conversion exceeded $30 \%$.

To conclude, passivation leads to the formation of a surface $\mathrm{CoO}$ layer. However, oxidation of the catalyst still progresses with time, leading to the formation of a thicker $\mathrm{CoO}$ layer, which results in deactivation of the catalysts with time. This phenomenon is more intensive when the post-treatment is conducted for longer time (i.e. for $2 \mathrm{~h}$ instead of $0.5 \mathrm{~h}$ ). However, it is possible to re-activate the catalyst by performing in situ $\mathrm{H}_{2}$ pre-treatment, under the reaction conditions (at $145^{\circ} \mathrm{C}$ ). Nevertheless, freshly reduced catalyst is still the most active in 2-octanol dehydrogenation. In the following investigations, experiments were performed in the presence of the 
catalysts reduced and passivated for $0.5 \mathrm{~h}$, and no longer than 2 weeks after the reduction-passivation post-treatment. No additional in situ $\mathrm{H}_{2}$ pre-treatment was conducted.

Table 2. Solvent effect on the conversion, selectivity and yields of 2-octanone and $\mathrm{H}_{2}$ for the dehydrogenation of 2-octanol [a]

\begin{tabular}{ccccc}
\hline Solvent & Boiling point $\left({ }^{\circ} \mathrm{C}\right)$ & $\mathrm{X}(\%)$ & $\mathrm{S}(\%)$ & $\mathrm{Y}(\%)$ \\
\hline Decane & 174 & 70 & 98 & 69 \\
Diisopentyl ether & 173 & 64 & $>99.9$ & 64 \\
o-Xylene & 145 & 65 & 99.0 & 64 \\
GVL & 207 & 0 & n.a. & 0 \\
DMSO & 189 & 0 & n.a. & 0 \\
\hline
\end{tabular}

[a] Reaction conditions: $0.5 \mathrm{~g}$ of $\mathrm{Co} / \mathrm{TiO}_{2} \mathrm{P} 25,0.95 \mathrm{~mol} \mathrm{~L}-1$ 2-octanol, $\mathrm{V}_{\text {total }}=45 \mathrm{~mL}, 24 \mathrm{~h}, 145^{\circ} \mathrm{C}$.

n.a. - not applicable

Table 3. Support effect in 2-octanol dehydrogenation [a]

\begin{tabular}{|c|c|c|c|c|}
\hline Catalyst & $\mathrm{X}(\%)$ & $\mathrm{S}(\%)$ & $\mathrm{Y}(\%)$ & $\mathrm{Y}_{\mathrm{H} 2}(\%)$ \\
\hline $\mathrm{Co} / \mathrm{TiO}_{2} \mathrm{P} 25$ & 70 & 98 & 69 & 64 \\
\hline $\mathrm{Co} / \mathrm{ZrO}_{2}$ & 10 & $>99.9$ & 10 & 7 \\
\hline $\mathrm{Co} / \mathrm{C}$ & 3 & n.a. & n.a. & 0 \\
\hline $\mathrm{CO}_{600} / \mathrm{C}^{[\mathrm{b}]}$ & 3 & n.a. & n.a. & 0 \\
\hline $\mathrm{Co} / \mathrm{Y}-\mathrm{Al}_{2} \mathrm{O}_{3}$ & 2 & n.a. & n.a. & 0 \\
\hline $\mathrm{Co}_{600} / \mathrm{Y}-\mathrm{Al}_{2} \mathrm{O}_{3}{ }^{[\mathrm{b}]}$ & 2 & n.a. & n.a. & 0 \\
\hline Co/ZnO & 3 & n.a. & n.a. & 0 \\
\hline $\mathrm{Co} / \mathrm{TiO}_{2} \mathrm{P} 90$ & 72 & 90 & 65 & 62 \\
\hline $\mathrm{Co} / \mathrm{TiO}_{2} \mathrm{SG}$ & 66 & 95 & 63 & 62 \\
\hline $\mathrm{Co} / \mathrm{TiO}_{2} \mathrm{NHSG}$ & 30 & 99.5 & 30 & 29 \\
\hline
\end{tabular}

[a] Reaction conditions: $0.5 \mathrm{~g}$ of catalyst, $0.95 \mathrm{~mol} \mathrm{~L}^{-1}$ 2-octanol, decane, $\mathrm{V}_{\text {total }}=45 \mathrm{~mL}, 24 \mathrm{~h}, 145^{\circ} \mathrm{C}$.

[b] Lower index in the name refers to the reduction temperature in ${ }^{\circ} \mathrm{C}$

n.a. - not applicable

\section{Solvent effect}

Reaction solvent can interact with reactants and/or catalyst, affecting the reaction results. ${ }^{[4]}$ Performance of $\mathrm{Co} / \mathrm{TiO}_{2} \mathrm{P}_{25}$ catalyst (reduced ex situ and passivated for $0.5 \mathrm{~h}$ ) in 2-octanol dehydrogenation was investigated in the presence of five different solvents (Table 2). Three of them were non-hydrogen-accepting, i.e. decane, diisopentyl ether and o-xylene, and two were hydrogen-accepting, namely $\gamma$-valerolactone (GVL) and dimethyl sulfoxide (DMSO). The highest activity was observed in decane (70\% of conversion), and slightly lower conversions (ca. 65\%) were obtained in diisopentyl ether and o-xylene. It is worth to notice that in diisopentyl ether no byproducts formation was observed, whereas in decane and o-xylene small amounts of additional C16 substances were formed. In GVL and DMSO no conversion was observed. When the test was conducted in GVL the reaction solution changed color from colorless to blue, suggesting that the catalyst was not stable and formation of cobalt-solvent complexes took place. After the reaction in DMSO the characteristic smell of DMS was noticeable from the reaction medium, also indicating that the catalyst and/or solvent were not stable in these reaction conditions.

To the best of our knowledge the solvent effect has never been addressed for the acceptor-less alcohol dehydrogenation. We determined decane to be the most suitable for the AAD reaction and it was further used as a solvent for all the catalytic tests.

\section{Support effect}

\section{Activity}

The nature of the support can influence the performance of a catalyst in the acceptor-less alcohol dehydrogenation. ${ }^{[18,22,24,29,31,34,36]}$ According to Shimizu et al., Co was the most active on amphoteric $\mathrm{TiO}_{2}$ as the carrier for the dehydrogenation of cyclododecanol. ${ }^{[36]}$ In this work, we aimed to investigate the effect of the support in the acceptor-less dehydrogenation of 2-octanol and also to examine the influence of the crystallographic composition of $\mathrm{TiO}_{2}$ on the catalyst activity.

Supports of different nature were used for the preparation of Co catalysts: amphoteric $\left(\mathrm{TiO}_{2} \mathrm{P} 25, \mathrm{ZrO}_{2}, \mathrm{Y}-\mathrm{Al}_{2} \mathrm{O}_{3}\right)$, neutral (C), and basic ( $\mathrm{ZnO}$ ). The corresponding catalytic results of 2-octanol dehydrogenation are gathered in Table 3. Among them, $\mathrm{Co} / \mathrm{TiO}_{2} \mathrm{P} 25 \mathrm{gave}$ the highest conversion of the alcohol (70\%), with very high selectivity towards 2-octanone (98\%) and high yield of $\mathrm{H}_{2}(64 \%)$. Co/ZrO catalyst was only slightly active, giving $10 \%$ of conversion, whereas, the other catalysts did not show any activity. The outstanding performance of $\mathrm{Co} / \mathrm{TiO}_{2}$ as well as the activity of $\mathrm{Co} / \mathrm{ZrO}_{2}$ were in line with the findings of Shimizu et al. in cyclododecanol dehydrogenation. ${ }^{[36]}$ However, $\mathrm{Co} / \mathrm{Y}-\mathrm{Al}_{2} \mathrm{O}_{3}$ and $\mathrm{Co} / \mathrm{C}$ were not active, in contrary to that previous study.

Afterwards, the influence of $\mathrm{TiO}_{2}$ crystallographic composition on the catalyst performance was studied and the corresponding results are gathered in Table 3. The oxide can exist in two main crystallographic forms: rutile and anatase. Beside $\mathrm{TiO}_{2} \mathrm{P} 25$ (composed of $25 \%$ of rutile and $75 \%$ of anatase), $\mathrm{TiO}_{2}$ SG (20\% rutile $+80 \%$ anatase, prepared by low-temperature sol-gel method), $\mathrm{TiO}_{2} \mathrm{P} 90$ (10\% rutile $+90 \%$ anatase), $\mathrm{TiO}_{2}$ DT51D (100\% anatase) and $\mathrm{TiO}_{2}$ NHSG (100\% anatase, prepared by non-hydrolytic sol-gel method) were also used. $\mathrm{Co} / \mathrm{TiO}_{2} \mathrm{SG}, \mathrm{Co} / \mathrm{TiO}_{2} \mathrm{P} 25$ and $\mathrm{Co} / \mathrm{TiO}_{2} \mathrm{P} 90$ showed good catalytic activity, with $66 \%, 70 \%$ and $72 \%$ of conversion, 
respectively. Co supported on anatase NHSG gave $30 \%$ of 2-octanol conversion, whereas Co supported on $\mathrm{TiO}_{2}$ anatase DT51D was not active.

For all the catalysts, the selectivity towards 2-octanone exceeded $90 \%$ after $24 \mathrm{~h}$. The observed by-products were C16 aldol condensation/dehydration products, and products of their subsequent hydrogenation. For all the catalysts the selectivity is above $99 \%$ at low conversion $(<30 \%)$, while at higher conversion the secondary reactions start to occur.

\section{Characterizations}

To better understand the different performances, the catalysts were characterized and the results are collected in Table 4. Elemental analysis confirmed an actual Co loading of $5 \mathrm{wt} \%$ in all the catalysts. The specific surface areas (SSAs) of catalysts were slightly lower than the SSAs of the supports, indicating some blocking of the pores.

XRD analysis was performed to assess the formation of metal nanoparticles, their crystallographic structure and also to estimate the mean crystallite size (Table 4). The diffractograms are presented in Figure 2. Cobalt nanoparticles can exist in two main crystallographic forms: hexagonal close packed (hcp) and face centered cubic (fcc). The thermal transition between them (hcp $\rightarrow$ fcc) occurs around $450{ }^{\circ} \mathrm{C}$ for bulk metal, ${ }^{[45]}$ hence, for catalysts reduced at $400{ }^{\circ} \mathrm{C}$, the coexistence of these two phases cannot be excluded. The main diffraction peak for hcp Co appears at $2 \theta$ equal to $47.6^{\circ}$ ((101) facet, PDF 00-005-0727), and for fcc Co at 44.2 ${ }^{\circ}$ ((111), PDF 00-0150806). For $\mathrm{Co} / \mathrm{TiO}_{2} \mathrm{P} 25$ (Figure 2.a) and $\mathrm{Co} / \mathrm{ZrO}_{2}$ (Figure 2.b) no signal from $\mathrm{Co}$ in metallic state was visible. But also, no signal from either $\mathrm{CoO}$ (main signal at $2 \theta=42.4^{\circ}$, (200), PDF 00-048-1719), nor $\mathrm{Co}_{3} \mathrm{O}_{4}\left(2 \theta=36.8^{\circ}\right.$ (311), PDF 00-009-0418), were present. On the diffractogram of $\mathrm{Co} / \mathrm{C}$ (Figure 2.c) the diffraction peak from $\mathrm{Co}_{3} \mathrm{O}_{4}$ is clearly visible, therefore the chosen reduction temperature was too low which explains the lack of activity. In the case of $\mathrm{Co} / \mathrm{y}-\mathrm{Al}_{2} \mathrm{O}_{3}$ (Figure 2.d) neither signals from Co, nor from any of the metal oxides are noticeable. In the literature, the formation of cubic $\mathrm{CoAl}_{2} \mathrm{O}_{4}$ was reported for $10 \mathrm{wt} \% \mathrm{Co} / \mathrm{Y}^{-}-\mathrm{Al}_{2} \mathrm{O}_{3},{ }^{[46]}$ but its main peak at $36.7^{\circ}$ overlap with the signal form the support (PDF 00-044-0160), and no conclusion about its presence can be made. The main peak at $44.2^{\circ}$ in $\mathrm{Co} / \mathrm{ZnO}$ (Figure 2.e) was recognizable and attributed to (111) plan of fcc Co with a mean crystallite size equal to $17 \mathrm{~nm}$. The formation of larger Co crystallites is probably connected with the low surface area of ZnO $\left(16 \mathrm{~m}^{2} \mathrm{~g}^{-1}\right)$.

The diffractograms of cobalt supported on different types of $\mathrm{TiO}_{2}$ are shown on Figure 3.a-d. For most of them, the diffraction peaks associated with metallic $\mathrm{Co}$ are not visible. Only for $\mathrm{Co} / \mathrm{TiO}_{2} \mathrm{NHSG}$ it was possible to see the main peak associated with fcc $\mathrm{Co}$ at $44.2^{\circ}$, with a mean crystallite size of $13 \mathrm{~nm}$. Thus, no significant differences between them were revealed by XRD analysis.

The reducibility of the catalysts was investigated by TGA- $\mathrm{H}_{2}$ technique and the corresponding graphs are presented in Figures S4.a, S7 and S8. Examples of the mass spectrometry signals recorded during the analyses are presented in Figure S9. The samples were calcined under air before the analysis, except for $\mathrm{Co} / \mathrm{C}$. We assumed that $\mathrm{Co}_{3} \mathrm{O}_{4}$ (amorphous or crystalline) is formed after calcination. The temperatures associated with the reduction of $\mathrm{Co}_{3} \mathrm{O}_{4}$ to $\mathrm{CoO}$, and subsequently to Co are included in Table 4 .

$\mathrm{Co} / \mathrm{TiO}_{2} \mathrm{P} 25$ and $\mathrm{Co} / \mathrm{ZrO}_{2}$ showed similar mass loss profiles and $\mathrm{CoO}$ was reduced into metallic $\mathrm{Co}$ at similar temperatures $\left(450{ }^{\circ} \mathrm{C}\right.$ and $440{ }^{\circ} \mathrm{C}$, respectively). Reduction profile of $\mathrm{Co} / \mathrm{C}$ is more complex, as both reduction of some oxygenated functional groups of the support and metal precursor decomposition took place, in addition to reduction of cobalt oxides. All in all, at $600{ }^{\circ} \mathrm{C}$ reduction of $\mathrm{Co} / \mathrm{C}$ catalyst is still on-going, in agreement with previous report. ${ }^{[4]} \mathrm{Co} / \mathrm{Y}-\mathrm{Al}_{2} \mathrm{O}_{3}$ was also not completely reduced at $600{ }^{\circ} \mathrm{C}$, what may be connected with the hindered reduction of $\mathrm{CoAl}_{2} \mathrm{O}_{4}$ species. ${ }^{[48]}$ On the other hand, $\mathrm{Co} / \mathrm{ZnO}$ was reduced at lower temperature than the other catalysts, i.e. $390^{\circ} \mathrm{C}$.

Considering the catalysts supported on different $\mathrm{TiO}_{2}$, the reduction temperature for $\mathrm{Co}_{3} \mathrm{O}_{4}$ was similar for all of them, in the range of $300-325^{\circ} \mathrm{C}$. However, for the reduction of $\mathrm{CoO}$, the temperature was in the range $375-500{ }^{\circ} \mathrm{C}$ (Table 4). Such high temperature span suggests different metal-support interaction strength and that after $\mathrm{H}_{2}$ treatment at $400^{\circ} \mathrm{C}$, Co might be reduced at different extent depending on the support.

Table 4. Characterization data for cobalt catalysts.

\begin{tabular}{|c|c|c|c|c|c|c|}
\hline \multirow[b]{2}{*}{ Catalyst } & \multirow{2}{*}{$\begin{array}{c}\text { Elemental analysis } \\
\text { - ICP - Co content } \\
(\%)^{[a]}\end{array}$} & \multirow[b]{2}{*}{$\begin{array}{l}\mathrm{N}_{2} \text { physisorption - } \\
\text { SSA }\left(\mathrm{m}^{2} \mathbf{g}^{-1}\right)^{[\mathrm{a}]}\end{array}$} & \multicolumn{2}{|c|}{$\overline{X R D^{[a]}}$} & \multicolumn{2}{|c|}{ TGA-H $2^{[b]}$} \\
\hline & & & $\begin{array}{l}\text { Reduced at } \\
400^{\circ} \mathrm{C}^{[c]}\end{array}$ & $\begin{array}{l}\text { Co crystallite size } \\
(\mathrm{nm})\end{array}$ & $\mathrm{Co}_{3} \mathrm{O}_{4} \rightarrow \mathrm{CoO}\left({ }^{\circ} \mathrm{C}\right)$ & $\mathrm{CoO} \rightarrow \mathrm{Co}\left({ }^{\circ} \mathrm{C}\right)$ \\
\hline $\mathrm{Co} / \mathrm{TiO}_{2} \mathrm{P} 25$ & 4.7 & 61 & + & $<10$ & 320 & 450 \\
\hline $\mathrm{Co} / \mathrm{ZrO}_{2}$ & 4.9 & 131 & + & $<10$ & 260 & 440 \\
\hline $\mathrm{Co} / \mathrm{C}$ & 4.8 & 1067 & - & n.a. & 350 & $>600$ \\
\hline $\mathrm{Co} / \mathrm{y}-\mathrm{Al}_{2} \mathrm{O}_{3}$ & 4.8 & 111 & $+/-$ & n.a. & 300 & $>600$ \\
\hline ColZnO & 4.9 & 15 & + & 17 & 250 & 390 \\
\hline $\mathrm{Co} / \mathrm{TiO}_{2} \mathrm{P90}$ & 4.8 & 118 & + & $<10$ & 310 & 500 \\
\hline $\mathrm{Co} / \mathrm{TiO}_{2} \mathrm{SG}$ & 4.9 & 111 & + & $<10$ & 310 & 410 \\
\hline $\mathrm{Co}_{\mathrm{TiO}} \mathrm{DT} \mathrm{D}$ & 5.0 & 84 & + & $<10$ & 320 & 375 \\
\hline $\mathrm{Co} / \mathrm{TiO}_{2}$ NHSG & 4.7 & 98 & + & 13 & 300 & 425 \\
\hline
\end{tabular}

SSA - specific surface area

n.a. - not applicable

a - for the calcined, reduced and passivated samples

b - for the calcined samples

${ }^{c}-(+)$ and $(-)$ refer to the presence $(+)$ or absence $(-)$ of Co metal after reduction at $400{ }^{\circ} \mathrm{C}$ 
TEM analysis was performed for two catalysts supported on $\mathrm{TiO}_{2}$, namely $\mathrm{Co} / \mathrm{TiO}_{2} \mathrm{P} 25$ and $\mathrm{Co} / \mathrm{TiO}_{2} \mathrm{DT} 51 \mathrm{D}$, and the chosen images are presented in Figure 4. Due to the low contrast between metal and the support it was not possible to measure the Co particle size distribution, neither to assess their crystallographic phases.

Figure 4. Examples of TEM images for (a) $\mathrm{Co} / \mathrm{TiO}_{2} \mathrm{P} 25$ and (b) $\mathrm{Co} / \mathrm{TiO}_{2} \mathrm{DT} 51 \mathrm{D}$; Co and $\mathrm{TiO}_{2}$ were labelled based on EDX analyses.

\section{Discussion}

Both $\mathrm{Co} / \mathrm{TiO}_{2} \mathrm{P} 25$ and $\mathrm{Co} / \mathrm{ZrO}_{2}$ catalysts were reduced at $400{ }^{\circ} \mathrm{C}$ (ex situ reduction temperature). TGA- $\mathrm{H}_{2}$ analyses suggest that $\mathrm{Co}$ is reduced at this temperature on these two supports, however the peaks of Co crystalline phases are not visible on their XRD diffractograms. Therefore the Co particles must be amorphous or small crystallites $(<10 \mathrm{~nm})$. Hence, the much lower activity of $\mathrm{Co}_{2} / \mathrm{ZrO} \mathrm{Z}_{2}$ $\left(10 \%\right.$ of conversion vs $70 \%$ for $\left.\mathrm{Co} / \mathrm{TiO}_{2} \mathrm{P} 25\right)$ in the reaction must result from the support effect. Further, for $\mathrm{Co} / \mathrm{C}$ and $\mathrm{Co} / \mathrm{Y}-\mathrm{Al}_{2} \mathrm{O}_{3}$ the analysis showed that a reduction temperature of $400{ }^{\circ} \mathrm{C}$ is not high enough to obtain metallic Co. This explains their lack of activity as $\mathrm{Co}^{0}$ is the active species in the reaction. To verify if a higher reduction temperature would improve their performance, catalytic tests with $\mathrm{Co} / \mathrm{C}$ and $\mathrm{Co} / \mathrm{Y}-\mathrm{Al}_{2} \mathrm{O}_{3}$ reduced at $600{ }^{\circ} \mathrm{C}$ (named $\mathrm{Co}_{600} / \mathrm{C}$ and $\mathrm{Co}_{600} / \mathrm{y}-\mathrm{Al}_{2} \mathrm{O}_{3}$ ) were conducted. However, this thermal treatment was not efficient and the catalysts were not active in the reaction (see Table 3). On the other hand, Co/ZnO was shown to be reduced but not active. There may be different reasons for this. First, larger Co NPs may not be active in AAD reaction. Further, the basic character of the support may not facilitate the reaction, as the reaction requires also the presence of Lewis acid sites. ${ }^{[34]}$ And last, due to the small surface area of $\mathrm{ZnO}$ and formation of larger nanoparticles, the metal-support interface is strongly limited, what may hinder the reaction, as it was shown for other metal catalysts (e.g. Pt/ $/ \mathrm{YAl}_{2} \mathrm{O}_{3},{ }^{[18]} \mathrm{Au} / \mathrm{HT},{ }^{\left[{ }^{[23-25]}\right.} \mathrm{Ag} / \mathrm{Al}_{2} \mathrm{O}_{3},{ }^{[28]} \mathrm{Ni} / \mathrm{O}-\mathrm{Al}_{2} \mathrm{O}_{3}{ }^{[34]}$ ).

Shimizu et al. investigated the influence of the support on the catalytic activity of cobalt in the dehydrogenation of cyclododecanol. ${ }^{[36]}$ According to their results, the conversion followed the order: $\mathrm{Co} / \mathrm{TiO}_{2} \gg \mathrm{Co} / \mathrm{Y}-\mathrm{Al}_{2} \mathrm{O}_{3} \approx \mathrm{Co} / \mathrm{C} \approx \mathrm{Co} / \mathrm{ZrO}_{2}$. The substrate was different and the supports were not the same (different suppliers or syntheses and textural properties) which prevents us from a straightforward comparison. Yet, our results are in line with this study as $\mathrm{Co} / \mathrm{TiO}_{2}$ is the best performing catalyst, and $\mathrm{Co} / \mathrm{ZrO} 2$, with amphoteric properties, is also mildly active in this reaction. On the other hand, $\mathrm{Co} / \mathrm{Y}-\mathrm{Al}_{2} \mathrm{O}_{3}$ and $\mathrm{Co} / \mathrm{C}$ were not active in the reaction with 2-octanol, which may result from different support properties in comparison with Shimizu et al. ${ }^{[0]}$

For the catalysts supported on various types of $\mathrm{TiO}_{2}$, lower activity was observed when Co was carried on pure anatase. Hence, rutile might favour the formation of active species. However, the synthesis of $\mathrm{TiO}_{2}$ in pure rutile phase with high specific surface is difficult and usually requires the addition of dopant, therefore, such catalyst was not prepared. The difference in performance between $\mathrm{Co}_{\mathrm{TiO}}$ DT51D and $\mathrm{Co} / \mathrm{TiO}_{2} \mathrm{NHSG}$ must be due to the different method of preparation of the support. Indeed, $\mathrm{TiO}_{2} \mathrm{NHSG}_{\text {was obtained by }}$ sol-gel non-hydrolytic method, using chloride precursor, whereas $\mathrm{TiO}_{2}$ DT51D was obtained by precipitation from sulphates. Therefore it cannot be excluded that the residual sulphates poison the Co metal. ${ }^{[49]}$

\section{Recycling and activity towards different alcohols}

$\mathrm{Co} / \mathrm{TiO}_{2} \mathrm{P} 25$ and $\mathrm{Co} / \mathrm{TiO}_{2} \mathrm{P} 90$, the two most active catalysts in the dehydrogenation of 2-octanol, were chosen for further tests of recycling and in the dehydrogenation of primary alcohol (1- octanol) and diol (1,2-octanediol). The corresponding results are gathered in Table 5.

Table 5. Catalytic results in the dehydrogenation of 2-octanol ( $1^{\text {st }}$ and $2^{\text {nd }}$ run), 1-octanol and 1,2-octanediol to octanal, 2-octanone and 1-hydroxy-2-octanone respectively [a]

\begin{tabular}{|c|c|c|c|c|c|}
\hline Catalyst & Substrate & $\mathrm{X}(\%)$ & S (\%) & $\mathrm{Y}(\%)$ & $\mathrm{Y}_{\mathrm{H} 2}(\%)$ \\
\hline \multirow{3}{*}{$\mathrm{Co} / \mathrm{TiO}_{2} \mathrm{P} 25$} & $\begin{array}{l}\text { 2-octanol } \\
1^{\text {st }} \text { run }\end{array}$ & 70 & 98 & 69 & 64 \\
\hline & $\begin{array}{l}\text { 2-octanol } \\
2^{\text {nd }} \text { run }\end{array}$ & 51 & $>99.9$ & 51 & 47 \\
\hline & $\begin{array}{c}\text { 1-octanol } \\
\text { 1,2-octanediol } \\
\end{array}$ & $\begin{array}{l}10 \\
33 \\
\end{array}$ & $\begin{array}{l}86 \\
90 \\
\end{array}$ & $\begin{array}{c}9 \\
30 \\
\end{array}$ & $\begin{array}{c}9 \\
28 \\
\end{array}$ \\
\hline \multirow{3}{*}{$\mathrm{Co} / \mathrm{TiO}_{2} \mathrm{P} 90$} & $\begin{array}{l}\text { 2-octanol } \\
1^{\text {st }} \text { run }\end{array}$ & 72 & 90 & 65 & 62 \\
\hline & $\begin{array}{l}\text { 2-octanol } \\
2^{\text {nd }} \text { run }\end{array}$ & 23 & $>99.9$ & 23 & 19 \\
\hline & $\begin{array}{c}\text { 1-octanol } \\
\text { 1,2-octanediol }\end{array}$ & $\begin{array}{c}2 \\
25\end{array}$ & $\begin{array}{l}\text { n.a. } \\
69\end{array}$ & $\begin{array}{c}2 \\
18 \\
\end{array}$ & $\begin{array}{c}2 \\
21 \\
\end{array}$ \\
\hline
\end{tabular}

[a] Reaction conditions: $0.95 \mathrm{~mol} \mathrm{~L}-1$ alcohol, decane, $\mathrm{V}_{\text {total }}=45 \mathrm{~mL}, 24 \mathrm{~h}, 145^{\circ} \mathrm{C} .0 .5 \mathrm{~g}$ of catalyst was used in the reaction of 2 -octanol (1 ${ }^{\text {st }}$ and $2^{\text {nd }}$ run), and 1 octanol dehydrogenation; $1.0 \mathrm{~g}$ of catalyst was used in the reaction of 1,2-octanediol. 
The two catalysts showed lower activity in the second run of 2-octanol dehydrogenation as the conversion dropped from ca. $70 \%$ to $51 \%$ and $23 \%$, respectively, for $\mathrm{Co} / \mathrm{TiO}_{2} \mathrm{P} 25$ and $\mathrm{Co} / \mathrm{TiO}_{2} \mathrm{P} 90$. It is worth to notice that in the second run $\mathrm{Co} / \mathrm{TiO} \mathrm{P}_{2} \mathrm{P} 25$ outperformed $\mathrm{Co} / \mathrm{TiO}_{2} \mathrm{P} 90$, which suggests a better stability under the reaction conditions.

The dehydrogenation of 1-octanol was conducted to assess the chemoselectivity of the catalysts towards dehydrogenation of secondary vs primary alcohol. $\mathrm{Co} / \mathrm{TiO}_{2} \mathrm{P} 25$ was mildly active towards primary alcohol dehydrogenation (10\% of conversion), while $\mathrm{Co} / \mathrm{TiO}_{2} \mathrm{P90}$ was almost not active. This points out the high chemoselectivity of Co catalysts towards dehydrogenation of secondary alcohol. Moreover, the selectivity in primary alcohol dehydrogenation towards the corresponding aldehyde was not complete, and some C16 by-productsI were observed. By GC-GC analysis they were identified as coming from aldol condensation/dehydration reaction and possibly sequential hydrogenation. An example of obtained mass spectra is presented in Figure S10, and the proposed molecules structures are given in Figure S11.

At the end, the dehydrogenation of 1,2-octanediol was performed to study the chemoselectivity in the concomitant presence of primary and secondary hydroxyl group in the alcohol molecule. $\mathrm{Co} / \mathrm{TiO}_{2} \mathrm{P} 25$ and $\mathrm{Co} / \mathrm{TiO}_{2} \mathrm{P} 90$ gave $33 \%$ and $25 \%$ of alcohol conversion, respectively. The main reaction product was 1-hydroxy-2-octanone, but none of the catalysts were totally selective towards it (90\% and $69 \%$ selectivity for $\mathrm{Co} / \mathrm{TiO}_{2} \mathrm{P} 25$ and $\mathrm{Co} / \mathrm{TiO}_{2} \mathrm{P} 90$, respectively). The 2-hydroxyoctanal was never observed during the reactions. The observed by products were $\mathrm{C} 16$ condensation products, similarly as for the monoalcohols.

Even though $\mathrm{Co} / \mathrm{TiO}_{2} \mathrm{P} 25$ was mildly active towards primary alcohol dehydrogenation, it occurred to be more active and selective than $\mathrm{Co} / \mathrm{TiO}_{2} \mathrm{P90}$ in the dehydrogenation of diol. In the literature, only one example of 1,2-octanediol dehydrogenation is available. ${ }^{[50]}$ The reported reaction was conducted in solvent-free conditions at $175{ }^{\circ} \mathrm{C}$, using $0.35 \mathrm{~mol} \%$ of $\mathrm{Ni} / \mathrm{SiO}_{2}$ catalyst: a conversion of $28 \%$ and a selectivity of $64 \%$ were obtained. As a by-product 2-octanone was observed ( $18 \%$ selectivity). The $\mathrm{Co} / \mathrm{TiO}_{2} \mathrm{P}_{2} 5$ catalyst exhibits similar conversion, yet for a higher metal to alcohol ratio ( $1 \mathrm{~mol} \% \mathrm{vs} 0.35 \mathrm{~mol} \%)$. Nonetheless, it is more selective to the desired secondary $\mathrm{OH}$ group dehydrogenation product (90\%).

The post-reaction characterization was performed on the samples after the $2^{\text {nd }}$ catalytic run in the dehydrogenation of 2-octanol and after the dehydrogenation of 1,2-octanediol. No structural changes were observed by XRD analysis - no signal from either Co, CoO or $\mathrm{CO}_{3} \mathrm{O}_{4}$ were visible (Figure S12). Yet, ICP-OES analysis of liquids collected at the end of the reactions revealed some leaching of the metal into the solution during the experiments with 1,2-octanediol, whereas it was not observed for the reactions of 2-octanol (Table $\mathrm{S} 1$ ). Moreover, the leaching was more significant for $\mathrm{Co} / \mathrm{TiO}_{2} \mathrm{P} 90$ catalyst, which indicates its lower stability and might explain its lower activity in the recyclability test and in the diol dehydrogenation.

\section{Conclusion}

A range of cobalt catalysts was tested for 2-octanol dehydrogenation. Among the tested solvents, decane was shown to be the most adequate for this reaction. 2-octanone was the main product for all the catalysts. Hydrogen was produced in quantitative yield to 2octanone, which demonstrated an acceptor-less mechanism. The conversion strongly depended on the nature of the support, and in the case of $\mathrm{TiO}_{2}$ of its crystallographic composition. The reducibility of cobalt, the size of Co particles and their interaction with support, and the acid-basic properties of the materials affected the catalytic results. The highest activity (ca. $70 \%$ of conversion) was observed with cobalt supported on $\mathrm{TiO}_{2} \mathrm{P} 25, \mathrm{TiO}_{2} \mathrm{SG}$ and $\mathrm{TiO}_{2} \mathrm{P} 90$. During storage of the catalyst at room temperature, the formation of CoO proceeded with time, leading to complete deactivation after 6 months. Low conversion $(<10 \%)$ were observed in the dehydrogenation of 1-octanol. For the first time, the dehydrogenation of diol was tested over Co catalysts. A preferential dehydrogenation of the secondary $\mathrm{OH}$ group was found.

\section{Experimental Section}

The list of used chemical products and details on the characterization techniques (ICP-OES, N2 physisorption, XRD, TGA-H2, TEM) are in Supporting Information.

\section{Syntheses}

Synthesis of $\mathrm{TiO}_{2} \mathrm{SG}$

$\mathrm{TiO}_{2}$ SG was synthesized by low temperature sol-gel method. ${ }^{[51]}$ At first titanium isopropoxide (37.1 $\mathrm{mL}$ ) was hydrolyzed by aqueous solution of $\mathrm{HCl}$ (2 $\mathrm{mol} \mathrm{L}-1,62.5 \mathrm{~mL}$ ), under vigorous stirring, and then aged for $48 \mathrm{~h}$ at room temperature. Subsequently, polyethyleneglycol (used as porogen) was added to the solution, also under vigorous stirring. The resulting mixture was evaporated with rotary evaporator $\left(120 \mathrm{rpm}, 30{ }^{\circ} \mathrm{C}, \mathrm{p} \sim 0.08\right.$ atm, $1.5 \mathrm{~h} \rightarrow 120 \mathrm{rpm}$, $\left.50{ }^{\circ} \mathrm{C}, \mathrm{p} \sim 0.06 \mathrm{~atm}, 1.5 \mathrm{~h} \rightarrow 120 \mathrm{rpm}, 70^{\circ} \mathrm{C}, \mathrm{p} \sim 0.05 \mathrm{~atm}, 1.5 \mathrm{~h}\right)$, dried for $24 \mathrm{~h}$ under air at $110^{\circ} \mathrm{C}$, and calcined $\left(\right.$ air, $50 \mathrm{~mL} \mathrm{~min}^{-1}, 2^{\circ} \mathrm{C} \mathrm{min}{ }^{-1}, 400{ }^{\circ} \mathrm{C}$, $2 \mathrm{~h}$ ). The material possessed specific surface area of $121 \mathrm{~m}^{2} \mathrm{~g}^{-1}$. The XRD results (SI, Figure S13) show that the support is composed of $80 \%$ of TiO 2 anatase and $20 \%$ of $\mathrm{TiO}_{2}$ rutile. The identification and quantification of the phases was obtained by performing Rietveld refinement using Topas 5 software. 
$\mathrm{TiO}_{2}$ NHSG was prepared via non-hydrolytic sol-gel method using $\mathrm{TiCl}_{4}$ as precursor. $\mathrm{iPr}_{2} \mathrm{O}$ (2 equivalents relative to the precursor) was used as oxygen donor and $\mathrm{CH}_{2} \mathrm{Cl}_{2}(10 \mathrm{~mL})$ as solvent. Inside a glovebox under argon, the reagents were mixed in a stainless-steel digestion vessel equipped with a PTFE lining $(23 \mathrm{~mL})$. The sealed autoclave was heated in an oven under autogenous pressure for 3 days to $110^{\circ} \mathrm{C}$. The resulting precipitate was thoroughly washed with $\mathrm{CH}_{2} \mathrm{Cl}_{2}$, dried under vacuum at room temperature for $1 \mathrm{~h}$, then at $120^{\circ} \mathrm{C}$ for $6 \mathrm{~h}$ and calcined at $500^{\circ} \mathrm{C}$ for $5 \mathrm{~h}\left(\right.$ heating rate $10{ }^{\circ} \mathrm{C}$ min ${ }^{-1}$ ) in air. The material possessed specific surface area of $117 \mathrm{~m}^{2} \mathrm{~g}^{-1}$, and is composed of $100 \%$ of $\mathrm{TiO}_{2}$ anatase. ${ }^{[52]}$

\section{Synthesis of 5 wt\% supported cobalt catalysts}

All cobalt supported catalysts with nominal 5 wt $\%$ metal loading were synthesized by wet impregnation method. $\mathrm{Co}\left(\mathrm{NO}_{3}\right)_{2} \cdot 6 \mathrm{H}_{2} \mathrm{O}$ was used as metal precursors. Typically, $4.75 \mathrm{~g}$ of support, $28.28 \mathrm{~mL}$ of Co precursor aqueous solution $\left(0.15 \mathrm{~mol} \mathrm{~L}^{-1}\right)$, and ultra-pure water (75 $\left.\mathrm{mL}\right)$ were introduced into a flask. After stirring for $2 \mathrm{~h}$ (600 rpm, room temperature), the solution was evaporated using a rotary evaporator for $4 \mathrm{~h}\left(120 \mathrm{rpm}, 50{ }^{\circ} \mathrm{C} \mathrm{H}_{2} \mathrm{O}, \mathrm{p} \sim 0.05-\right.$ $0.06 \mathrm{~atm}$ ). To remove remaining moisture, the catalyst was dried overnight at $80^{\circ} \mathrm{C}$, under $\mathrm{N}_{2}$. The obtained solid was crushed in order to homogenize the powder. The sample was subsequently calcined (air, $40 \mathrm{~mL} \mathrm{~min}^{-1}, 1^{\circ} \mathrm{C} \mathrm{min}{ }^{-1}, 300{ }^{\circ} \mathrm{C}, 1 \mathrm{~h}$ ) and reduced $\left(\mathrm{H}_{2}, 40 \mathrm{~mL} \mathrm{~min}^{-1}, 1{ }^{\circ} \mathrm{C} \mathrm{min}{ }^{-1}, 400{ }^{\circ} \mathrm{C}, 0.5 \mathrm{~h}\right.$ ). Some of the samples were also passivated $\left(1 \% \mathrm{v} / \mathrm{v} \mathrm{O}_{2} / \mathrm{N}_{2}, 50 \mathrm{~mL} \mathrm{~min} \mathrm{~m}^{-1}\right.$, room temperature, $\left.0.5-2 \mathrm{~h}\right)$. For Co/C the calcination step was omitted. The catalysts were stored inside a glovebox, under $\mathrm{N}_{2}$ atmosphere.

\section{Catalytic tests}

Reaction conditions

Catalytic tests were performed in different solvents (mainly n-decane, but also diisopentyl ether, o-xylene, GVL, and DMSO), for $24 \mathrm{~h}$, at $145{ }^{\circ} \mathrm{C}$. In the reactions of monoalcohols (1-octanol and 2-octanol) $0.5 \mathrm{~g}$ of catalyst was used per experiment ( 1 mol\% of metal towards the substrate), while in reactions of diol (1,2-octanediol) $1.0 \mathrm{~g}$ of catalyst was used ( $2 \mathrm{~mol} \%$ of metal towards the substrate). The reactions were conducted in a $100 \mathrm{~mL}$ semi-batch glass reactor. Total volume of the reaction solution was equal to $45 \mathrm{~mL}$, with the concentration of alcohol of $0.95 \mathrm{~mol}^{-1}$. The inert atmosphere was ensured by a constant flow of a mixture of inert gases through the reactor $\left(10 \% \mathrm{~N}_{2}\right.$ and $90 \%$ Ar, total flow $\left.30 \mathrm{~mL} \mathrm{~min}^{-1}\right)$. The reaction mixture was mechanically stirred $(750 \mathrm{rpm})$ during the whole course of the experiment.

\section{Monitoring reaction progress}

The progress of catalytic tests was followed in two ways: by online analysis of the reaction gases mixture (inert gases flowing through the reactor and produced $\left.\mathrm{H}_{2}\right)$ and by analysis of liquid aliquots $(0.50-0.75 \mathrm{~mL}$ each) collected periodically during the reaction. The outlet of gases from the reactor was coupled with a gas chromatograph (Shimadzu GC-2010, Supelco Carboxen-1010 PLOT column $30 \mathrm{~m} \times 0.53 \mathrm{~mm}$; thermal program: isotherm, $50{ }^{\circ} \mathrm{C}$, Ar as a carrier gas, TCD detector). $\mathrm{N}_{2}$ was used as an internal standard for $\mathrm{H}_{2}$ measurement, whose quantification was based on the ratio between the integrations of these two signals, after calibration. Liquid samples were also analyzed by gas chromatography (Shimadzu GC-2010, column ZB-FFAP $30 \mathrm{~m} \times 0.32 \mathrm{~mm} \times 0.25 \mu \mathrm{m}$, thermal program: $40^{\circ} \mathrm{C} \rightarrow 230{ }^{\circ} \mathrm{C}, 20^{\circ} \mathrm{C} \mathrm{min}-1,230{ }^{\circ} \mathrm{C}, 10 \mathrm{~min}, \mathrm{~N}_{2}$ as carrier gas, FID detector) to evaluate the alcohol and product(s) concentration. Quantification was performed after calibration of their solutions of different concentrations in reaction solvent. The main reaction products were: 2-octanone, octanal and 1-hydroxy-2-octanone, from secondary alcohol, primary alcohol and diol, respectively. Some C16 by-products were also observed during the reaction.

\section{By-products identification}

Two-dimensional gas chromatography (GC-GC), coupled with mass spectrometry, was performed to identified the reaction by-products. Agilent 6890N gas chromatograph (GC) with ZOEX cryogenic modulation system for GC-GC, and equipped with MS Agilent 5975B mass spectra detector, was used. GC was equipped with two columns: (1) ZB5 (30 m x $0.25 \mathrm{~mm} \times 0.25 \mu \mathrm{m})$ and (2) VF17 (1.5 $\mathrm{m} \times 0.10 \mathrm{~mm} \times 0.20 \mu \mathrm{m})$. The thermal programs for columns were as followed: (1) $50{ }^{\circ} \mathrm{C}, 5 \mathrm{~min}$; gradient $50{ }^{\circ} \mathrm{C} \rightarrow 300{ }^{\circ} \mathrm{C}, 1.75^{\circ} \mathrm{C} \mathrm{min}{ }^{-1}$; and (2) isotherm $50{ }^{\circ} \mathrm{C}, 2$ min; gradient $50{ }^{\circ} \mathrm{C} \rightarrow 330{ }^{\circ} \mathrm{C}, 1.80{ }^{\circ} \mathrm{C}$ min ${ }^{-1}$; isotherm $330^{\circ} \mathrm{C}, 2 \mathrm{~min}$. Helium was used as carrier gas. The masses were scanned in the range of $\mathrm{m} / \mathrm{z}=33-280$. Obtained data were processed with GCimage software v2.2.

In situ $\mathrm{H}_{2}$ pre-treatment

The catalyst and part of the solvent $(30 \mathrm{~mL})$ were introduced into the reactor and heated up to $145{ }^{\circ} \mathrm{C}$, under a constant flow of inert gases (10\% $\mathrm{N}_{2}$ and $\left.90 \% \mathrm{Ar}, 30 \mathrm{~mL} \mathrm{~min}^{-1}\right)$ and with mechanical stirring $(750 \mathrm{rpm})$. When the given temperature was reached, the flow of $\mathrm{H}_{2}$ was switched on $\left(10 \mathrm{~mL}^{\mathrm{min}}{ }^{-1}\right)$ and kept for $1 \mathrm{~h}$. After this time, it was switched off, and only inert gases were flown for the next $1 \mathrm{~h}$ to remove the remaining $\mathrm{H}_{2}$ from the reactor, which was monitored by online gas chromatography. After that, the mixture of the remaining volume of solvent and alcohol substrate were added to the reactor and the catalytic experiment was started.

\section{Conditions for recycling tests}

A first reaction test of dehydrogenation of 2-octanol was conducted with doubled mass of catalyst (i.e. $1.0 \mathrm{~g}$ instead of $0.5 \mathrm{~g}$ ). The solid was recovered after experiment, washed intensively with ethanol, and dried under $\mathrm{N}_{2}$ atmosphere. From the recovered sample, $0.5 \mathrm{~g}$ was taken for the second run. It was re-activated by in situ $\mathrm{H}_{2}$ pre-treatment procedure and reaction was started as described above.

Results analysis

Conversion of the substrate $\mathrm{X}$ is defined as:

$$
X(\%)=\left(1-\frac{C_{x}}{C_{0}}\right) \cdot 100
$$


where:

$\mathrm{C}_{\mathrm{x}}$ - concentration of alcohol at a given time

$\mathrm{C}_{0}-$ initial concentration of alcohol

Selectivity to carbonyl is defined as:

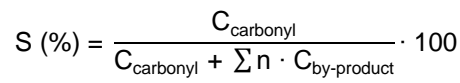

C carbonyl - concentration of desired carbonyl compound (aldehyde, ketone, and hydroxyketone for primary alcohol, secondary alcohol, and diol, respectively) at a given time

Cby-product - concentration of byproduct(s) at a given time

$\mathrm{n}$ - coefficient factor, equal to 2 for C16 molecules

The carbon balance was above $95 \%$ for all the reactions.

The yield of produced $\mathrm{H}_{2}$ was evaluated as:

$$
\mathrm{Y}_{\mathrm{H}_{2}}(\%)=\frac{\mathrm{n}_{\mathrm{H}_{2}}}{\mathrm{n}_{\text {theor }}} \cdot 100
$$

where:

$\mathrm{n}_{\mathrm{H}_{2}}$ - accumulated amount of $\mathrm{H}_{2}$, produced after given time of reaction

$\mathrm{n}_{\text {theor }}$ - theoretical amount of $\mathrm{H}_{2}$ produced during the reaction, equal to the initial amount of alcohol (cf Scheme 1)

\section{Acknowledgements}

The authors would like to thank the ANR agency for the founding of the TANOPOL project (ANR-15-CE07-0011-01). Also we are grateful to $\mathrm{H}$. Mutin, J. Alauzun and M. Bouchneb from Institut Charles Gerhardt Montpellier (France) for supplying $\mathrm{TiO}_{2} \mathrm{NHSG}$, to $\mathrm{C}$. Lorentz, R. Checa and scientific services from IRCELYON for their help with analytical techniques.

\section{References}

[1] S. M. A. H. Siddiki, T. Toyao, K. Shimizu, Green. Chem. 2018, 20, 2933

[2] A. M. F. Phillips, A. J. L. Pombeiro, M. N. Kopylovich, ChemCatChem 2017, 9, 217

[3] G. Tojo, M. Fernández, Oxidation of alcohols to aldehydes and ketones, Sringer, New York, 2010

[4] John McMurry, Organic Chemistry, Cengage Learning, 2011.

[5] R. A. Sheldon, J. K. Kochi, Metal-Catalyzed Oxidations of Organic Compounds, Academic Press, 1981.

[6] F. Zaccheria, N. Ravasio, R. Psaro, A. Fusi, Chem. Eur J. 2006, 12, 6426.

[7] J.-E. Bäckvall, J. Organomet. Chem. 2002, 652, 105

[8] W. Hu, Y. Zhang, H. Zhu, D. Ye, D. Wang, Green Chem. 2019, 21, 5345.

[9] Q. Yang, Y. Zhang, W. Zeng, Z.-C. Duan, X. Sang, D. Wang, Green Chem. 2019, 21, 5683.

[10] Z. Wu, D.-S. Wang, X. Yu, Y. Yang, D. Wang, Adv. Synth. Catal. 2017, 359, 3332.

[11] R. J. Angelici, ACS Catal. 2011, 1, 772.

[12] A. F. Dalebrook, W. Gan, M. Grasemann, S. Moret, G. Laurenczy, Chem. Commun. 2013, 49, 8735.

[13] E. Buckley, E. F. G. Herington, Trans. Faraday Soc. 1965, 61, 1618.

[14] A. H. Cubberley, M. B. Mueller, J. Am. Chem. Soc. 1946, 68, 1149.

[15] C. Gunanathan, D. Milstein, Science 2013, 341, 1229712.

[16] S. Werkmeister, J. Neumann, K. Junge, M. Beller, Chem. Eur. J. 2015, 21, 12226.

[17] G. A. Filonenko, R. van Putten, E. J. M. Hensen, E. A. Pidko, Chem. Soc. Rev. 2018, 47, 1459.

[18] K. Kon, S. M. A. Hakim Siddiki, K. Shimizu, J. Catal. 2013, 304, 63.

[19] G. Nicolau, G. Tarantino, C. Hammond, ChemSusChem 2019, 12, 4953.

[20] R. Karvembu, S. Priyarega, React. Kinet. Catal. Lett. 2006, 88, 333.

[21] W.-H. Kim, I. S. Park, J. Park, Org. Lett. 2006, 8, 2543.

[22] K. Kon, W. Onodera, T. Toyao, K. Shimizu, Catal. Sci. Technol. 2016, 6, 5864.

[23] W. Fang, Q. Zhang, J. Chen, W. Deng, Y. Wang, Chem. Commun. 2010, 46, 1547

[24] W. Fang, J. Chen, Q. Zhang, W. Deng, Y. Wang, Chem. Eur. J. 2011, 17, 1247.

[25] J. Chen, W. Fang, Q. Zhang, W. Deng, Y. Wang, Chem. Asian J. 2014, 9, 2187

[26] H. Liu, H.-R. Tan, E. S. Tok, S. Jaenicke, G.-K. Chuah, ChemCatChem 2016, 8, 968.

[27] T. Mitsudome, Y. Mikami, H. Funai, T. Mizugaki, K. Jitsukawa, K. Kaneda, Angew. Chem. Int. Ed. 2008, $47,138$.

[28] K. Shimizu, A. Satsuma, J. Jpn. Pet. Inst. 2011, 54, 347.

[29] K. Shimizu, K. Sugino, K. Sawabe, A. Satsuma, Chem. Eur. J. 2009, 15, 2341.

[30] A. Bayat, M. Shakourian-Fard, N. Ehyaei, M. Mahmoodi Hashemi, RSC Adv. 2015, 5, 22503.

[31] T. Mitsudome, Y. Mikami, K. Ebata, T. Mizugaki, K. Jitsukawa, K. Kaneda, Chem. Commun. 2008, 4804

[32] D. Damodara, R. Arundhathi, P. R. Likhar, Adv. Synth. Catal. 2014, 356, 189.

[33] Y. Zhu, M. Shen, Y. Xia, M. Lu, Appl. Organomet. Chem. 2015, 29, 152.

[34] K. Shimizu, K. Kon, K. Shimura, S. S. M. A. Hakim, J. Catal. 2013, 300, 242.

[35] H. Chen, S. He, M. Xu, M. Wei, D. G. Evans, X. Duan, ACS Catal. 2017, 7, 2735.

[36] K. Shimizu, K. Kon, M. Seto, K. Shimura, H. Yamazaki, J. N. Kondo, Green Chem. 2013, 15, 418.

[37] A. Lyalin, K. Shimizu, T. Taketsugu, J. Phys. Chem. C 2017, 121, 3488.

[38] J. Yi, J. T. Miller, D. Y. Zemlyanov, R. Zhang, P. J. Dietrich, F. H. Ribeiro, S. Suslov, M. M. Abu-Omar, Angew. Chem. Int. Ed. 2014, 53, 833.

[39] V. L. Sushkevich, I. I. Ivanova, E. Taarning, ChemCatChem 2013, 5, 2367. 
[40] M. Neurock, Z. Tao, A. Chemburkar, D. D. Hibbitts, E. Iglesia, Faraday Discuss. 2017, 197, 59

[41] M. E. Sad, M. Neurock, E. Iglesia, J. Am. Chem. Soc. 2011, 133, 20384

[42] F. Huber, Z. Yu, S. Lögdberg, M. Rønning, D. Chen, H. Venvik, A. Holmen, Catal. Lett. 2006, 110, 211.

[43] M. Wolf, N. Fischer, M. Claeys, Catal. Today 2016, 275, 135.

[44] P. J. Dyson, P. G. Jessop, Catal. Sci. Technol. 2016, 6, 3302

[45] B. W. Lee, R. Alsenz, A. Ignatiev, M. A. Van Hove, Phys. Rev. B 1978, 17, 1510

[46] L. Ji, J. Lin, H. C. Zeng, J. Phys. Chem. B 2000, 104, 1783

[47] Y. Sun, G. Zhang, J. Liu, P. Zhao, P. Hou, Y. Xu, R. Zhang, Int. J. Hydrogen Energy 2018, 43, 1497.

[48] R. Bechara, D. Balloy, J.-Y. Dauphin, J. Grimblot, Chem. Mater. 1999, 11, 1703.

[49] N. E. Tsakoumis, M. Rønning, Ø. Borg, E. Rytter, A. Holmen, Catal. Today 2010, 154, 162.

[50] B. Guicheret, Y. Bertholo, P. Blach, Y. Raoul, E. Métay, M. Lemaire, ChemSusChem 2018, 11, 3431.

[51] F. Bosc, A. Ayral, N. Keller, V. Keller, Appl. Catal. B 2007, 69, 133.

[52] Y. Wang, M. Bouchneb, J.G. Alauzun, P.H. Mutin, Molecules 2018, 23, 3006 